\title{
Inhibitory effects of H-Ras/Raf-1-binding affibody molecules on synovial cell function
}

\author{
Seiji Shibasaki ${ }^{1,2,3}$, Miki Karasaki ${ }^{3}$, Torbjörn Gräslund ${ }^{4}$, Per-Åke Nygren ${ }^{4}$, Hajime Sano ${ }^{3}$ and Tsuyoshi Iwasaki ${ }^{2,3,5}$
}

\begin{abstract}
Affibody molecules specific for H-Ras and Raf-1 were evaluated for their ability to inhibit synovial cell function. Affibody molecules targeting $\mathrm{H}$-Ras $\left(Z_{\text {ras122, }} Z_{\text {ras220, }}\right.$ and $\left.Z_{\text {ras521 }}\right)$ or Raf-1 $\left(Z_{\text {raf322 }}\right)$ were introduced into the MH7A synovial cell line using two delivery methods: transfection with plasmids encoding the affibody molecules or direct introduction of affibody protein using a cell-penetrating peptide reagent. Interleukin-6 (IL-6) and prostaglandin E2 (PGE2) production by MH7A cells were analyzed by enzyme-linked immunosorbent assay after stimulation with tumor necrosis factor-alpha (TNF-a). Cell proliferation was also analyzed. Phosphorylation of extracellular signal-regulated kinase (ERK) was analyzed by western blot. All affibody molecules could inhibit IL-6 and PGE2 production in TNF-a-stimulated MH7A cells. The inhibitory effect was stronger when affibody molecules were delivered as proteins via a cell-penetrating peptide reagent than when plasmid-DNA encoding the affibody moelcules was transfected into the cells. Plasmid-expressed $Z_{\text {ras220 }}$ inhibited phosphorylation of ERK in TNF-a-stimulated MH7A cells. Protein-introduced $Z_{\text {raf322 }}$ inhibited the production of IL-6 and PGE2 and inhibited cell proliferation in MH7A cells. These findings suggest that affibody molecules specific for $\mathrm{H}$-Ras and Raf-1 can affect intracellular signal transduction through the MAP kinase pathway to inhibit cell proliferation and production of inflammatory mediators by synovial cells.
\end{abstract}

Keywords: Affibody molecules; Inflammation; Interleukin-6; Intracellular signal transduction; Prostaglandin E2; Rheumatoid arthritis

\section{Introduction}

Rheumatoid arthritis (RA) is an inflammatory disease characterized by the progressive destruction of joints. In RA, hyperplasia of synovial lining cells is observed along with angiogenesis and inflammatory mononuclear cell infiltration (Kitano et al. 2006). A wide variety of molecules produced by both synovial cells and infiltrating inflammatory mononuclear cells is thought to be involved in RA pathology. Specifically, proinflammatory cytokines such as interleukin-6 (IL-6), IL-17 (Schlegel et al. 2013) and tumor necrosis factor alpha (TNF- $\alpha$ ) play a key role in RA pathogenesis, including the activation of synovial fibroblasts, osteoclasts, and inflammatory mononuclear cells, which results in irreversible damage to the soft tissues and bones (Olsen and Stein 2004).

\footnotetext{
* Correspondence: seiji@huhs.ac.jp

${ }^{1}$ General Education Center, Hyogo University of Health Sciences, 1-3-6

Minatojima, Chuo-ku, Kobe 650-8530, Japan

${ }^{2}$ Graduate School of Pharmacy, Hyogo University of Health Sciences, 1-3-6

Minatojima, Chuo-ku, Kobe 650-8530, Japan

Full list of author information is available at the end of the article
}

One of the conventional disease-modifying antirheumatic drugs (DMARDs), methotrexate, is the standard for RA pharmacotherapy (Upchurch and Kay 2012). However, its treatment outcomes are not satisfactory and often cause high levels of toxicity and adverse effects for patients (Smolen and Steiner 2003). In recent years, various biological agents have been developed and used clinically as important options for RA treatment (Saag et al. 2008). These biological agents include an antiCD20 antibody (rituximab) (Mélet et al. 2013), TNF antagonists (e.g., adalimumab, etanercept, golimumab, and infliximab), an IL-6 receptor antagonist (tocilizumab) (Smolen and Aletaha 2011), and a recombinant fusion protein consisting of the extracellular domain of human CTLA-4 (abatacept) (Gómez-Reino 2012). Although these biological agents provide favorable treatment outcomes for RA patients, in view of medical economics, biological therapies are more costly than traditional DMARDs. Thus, 
a more cost-effective treatment option is desirable because healthcare payers and providers are conscious of cost in light of the current period of budget constraints (Furneri et al. 2012).

Several biologically active, non-immunoglobulin-based proteins have been created as candidates of novel biological agents. For instance, a monobody is a targetbinding protein that is generated from the fibronectin type III domain (Koide et al. 2012). Synthetic ankyrin repeat proteins have a binding scaffold and are potential diagnostic and therapeutic tools (Baumann et al. 2007). In this study, we investigated another class of nonimmunoglobulin ligands, referred to as affibody molecules. They are engineered binding proteins based on a scaffold of the three- $\alpha$-helix bundle Z-domain (Friedman and Ståhl 2009; Nilsson and Tolmachev 2007; Nygren 2008). The $6-\mathrm{kDa} \mathrm{Z}$-domain is derived from the B-domain, one of the five domains in Staphylococcus aureus protein A (Gunneriusson et al. 1996).

Affibody molecules associated with signal transduction or transcription in tumor development or immune responses have been screened and applied. For example, affibody molecules against c-Jun, an oncogenic transcription factor, have been selected and are able to detect c-Jun in a melanoma cell line (Lundberg et al. 2009). Furthermore, other affibody molecules against human epidermal growth factor receptor (HER), specifically HER2 (Lindberg et al. 2012) and HER3 (Malm et al. 2013), have been investigated.

We have previously reported the selection of $\mathrm{H}$-Rasbinding or Raf-1-binding affibody molecules (Grimm et al. 2010). Affibody clones $Z_{\text {ras122 }}, Z_{\text {ras220, and }} Z_{\text {raf322 }}$ were isolated by phage display selection from a library, and the specificity and affinity for H-Ras or Raf-1 proteins were determined in that study. Each molecule was demonstrated to selectively bind Ras or Raf-1 proteins, but not other human control proteins. $Z_{\text {ras122, }} Z_{\text {ras220, }}$, and $Z_{\text {raf322 }}$ had binding affinities in the high nanomolar to low micromolar range, as demonstrated by a realtime biospecific interaction analysis. As an alternative or complement to current RA treatment regimens, these affibody molecules might have the potential to inhibit signal transduction mediated by Ras and Raf, since this signaling is thought to be important for efficient synthesis of several inflammatory mediators (Yamamoto et al. 2003).

In this study, we investigated the effect of introducing $\mathrm{H}$-Ras-binding and Raf-1-binding affibody molecules in the MH7A synovial cell line (Tsunemi et al. 2010). First, we subcloned DNA encoding affibody molecules against $\mathrm{H}$-Ras or Raf-1 into a plasmid DNA vector for mammalian expression, and the vectors were introduced into MH7A cells. Then, affibody proteins were produced using an Escherichia coli expression system and were introduced into MH7A cells. We investigated inhibition caused by H-Ras- or Raf-1-targeting affibody molecules on the production of the inflammatory mediators IL-6 and prostaglandin E2 (PGE2). Furthermore, we examined proliferation of MH7A cells.

\section{Materials and methods \\ Cell line}

The human MH7A synovial cell line (Riken, Saitama, Japan), which originated from intra-articular soft tissue of the knee joints of an RA patient, was established by transfection with the SV40 T antigen (Miyazawa et al. 1998). MH7A cells were cultured in RPMI 1640 (Sigma, St. Louis, MO, USA) containing 10\% heat-inactivated fetal bovine serum (Whittaker, Walkersville, MD, USA), 100 units $/ \mathrm{mL}$ of penicillin, and $100 \mu \mathrm{g} / \mathrm{mL}$ of streptomycin (Invitrogen, $\mathrm{CA}, \mathrm{USA}$ ) at $37^{\circ} \mathrm{C}$ in an atmosphere of $5 \%$ $\mathrm{CO}_{2}$ in air.

\section{Plasmid construction for affibodies and introduction into MH7A cells}

The plasmids that were used to produce affibodies in mammalian cells were constructed by first amplifying DNA encoding anti-H-Ras and anti-Raf-1 affibodies $\left(Z_{\text {ras122 }}, Z_{\text {ras220 }}, Z_{\text {ras521 }}\right.$, and $\left.Z_{\text {raf322 }}\right)$ by PCR using primers 5'-AAGGGGATCCACCATGGGCAGCAGCCATCATCA 'TCA-3' and 5' -AGGGGTTATGCTAGTTATTGCTCAG CGCGGAATTCTTA-3' (Grimm et al. 2010). DNA sequences of affibody molecules are listed the additional file (Additional file 1). Each fragment was inserted into the multiple cloning site of pcDNA3.1(+) (Invitrogen). The nucleotide sequences of these constructs were confirmed by sequencing with an ABI PRISM 3100 Genetic Analyzer (Applied Biosystems, Foster City, CA, USA). Constructs were introduced into MH7A cells for transient expression using Lipofectamine 2000 (Invitrogen) following the manufacturer's instructions. Cells used for transfection were seeded at $1.7 \times 10^{5}$ cells/well in a 24-well plate (BD, Franklin Lakes, NJ, USA) and cultured for $1 \mathrm{~d}$ before transfection.

\section{Western blot analysis of affibody expression}

MH7A cells transfected with affibody-encoding plasmids $\left(1 \times 10^{7}\right)$ were plated in a 24-well plate. After 48 or $72 \mathrm{~h}$ of incubation, cells were lysed in Mammalian Lysis Buffer from the Qproteome Mammalian Protein Prep Kit (Qiagen, Hilden, Germany), and protein content was determined using the Bio-Rad Protein Assay Reagent (Bio-Rad, Hercules, CA, USA) with bovine serum albumin as the standard. Each sample was resolved by SDSPAGE on $20 \%$ polyacrylamide gels and then transferred to $0.45-\mu \mathrm{m}$ nitrocellulose membranes. After blocking overnight at $4^{\circ} \mathrm{C}$ with Blocking One Solution (Nacalai Tesque, Kyoto, Japan), membranes were incubated with 
goat polyclonal antibody specific for the affibody (Abcam, Cambridge, UK) as the primary antibody (1:400 dilution in phosphate-buffered saline; PBS) overnight at $4^{\circ} \mathrm{C}$. After washing the membranes with Tris-buffered saline-0.05\% Tween 20 (washing buffer), target proteins were detected with alkaline phosphatase (AP)-labeled ReserveAP Rabbit anti-goat immunoglobulin G (IgG) (KPL, Gaithersburg, MD, USA; 1:1,000 dilution in 1\% PBS containing 0.05\% Tween 20). NBT/BCIP (Roche, Mannheim, Germany) was used as the AP colorimetric substrate for visualization.

\section{Measurement of IL-6 or PGE2 levels}

MH7A cells $\left(2 \times 10^{4}\right)$ that were transfected with an affibody-encoding plasmid were plated in a 24-well plate and cultured in the presence or absence of $100 \mathrm{ng} / \mathrm{mL}$ TNF- $\alpha$. After 24 or $48 \mathrm{~h}$ of incubation, IL-6 and PGE2 levels were determined by assaying supernatants with an Enzyme-Linked Immunosorbent Assay (ELISA) Kit for IL-6 (R\&D Systems, Minneapolis, MN, USA) or PGE2 (ENZO Life Sciences, Farmingdale, NY, USA), respectively, according to the instructions.

\section{Cell proliferation studies}

Cell viability was determined using a Cell Counting Kit (CCK)-8 (Dojindo, Kumamoto, Japan), in which 2-(2methoxy-4-nitrophenyl)-3-(4-nitrophenyl)-5-(2,4-disulfophenyl)-2H-tetrazolium monosodium salt was used as a substrate (Ohuchida et al. 2004). Absorbance was measured using a SpectraMax M2 Microplate Reader (Molecular Devices, Sunnyvale, CA, USA) at $450 \mathrm{~nm}$ (Shibasaki et al. 2012).

\section{Western blot analysis for phosphorylated extracellular signal-regulated kinase ( $p$-ERK)}

Western blot analysis was performed as described above. Briefly, MH7A cells transfected with affibody-encoding plasmids $\left(1 \times 10^{7}\right)$ were plated in a 24-well plate, incubated for $24 \mathrm{~h}$, and then stimulated with $100 \mathrm{ng} / \mathrm{mL}$ TNF- $\alpha$ (Sigma). After an additional incubation of 16 or $24 \mathrm{~h}$, the soluble fraction of the cells was analyzed by western blot analysis using IgG against p-ERK (Santa Cruz Biotechnology, Dallas, TX, USA) as a primary antibody. Goat polyclonal IgG against actin (Santa Cruz) was used as a control.

\section{Affibody protein production in $E$. coli}

Expression of the pAffi- $Z_{\text {ras122 }},-Z_{\text {ras220 }},-Z_{\text {ras521 }}$, and $-Z_{\text {raf322 }}$ plasmids in E. coli BL21(DE3) produced H-Ras and Raf- 1 affibody molecules with an N-terminal $6 \times$ His tag. The E. coli cells were inoculated in $2 \mathrm{~mL}$ of Luria-Bertani (LB) broth containing $100 \mu \mathrm{g} / \mathrm{L}$ ampicillin and were incubated in a shaking incubator overnight at $37^{\circ} \mathrm{C}$. The $2-\mathrm{mL}$ overnight cultures were used to inoculate fresh LB medium containing $100 \mu \mathrm{g} / \mathrm{L}$ ampicillin $(125 \mathrm{~mL})$, and cultures were grown at $37^{\circ} \mathrm{C}$ to an $\mathrm{OD}_{600}$ of $0.6-0.7$. Gene expression was then induced by the addition of isopropyl $\beta$-D-thiogalactoside (Wako Pure Chemical, Osaka, Japan) to a final concentration of $1 \mathrm{mM}$. After 3-4 h of incubation at $37^{\circ} \mathrm{C}$, the cells were harvested by centrifugation $\left(4,000 \times g, 15 \mathrm{~min}, 4^{\circ} \mathrm{C}\right)$. The cell pellets were subsequently resuspended in $10 \mathrm{~mL}$ of B-PER Bacterial Protein Extraction Reagent (Thermo Fisher Scientific, Waltham, MA, USA) and shaken gently for $10 \mathrm{~min}$ at room temperature $\left(25^{\circ} \mathrm{C}\right)$. Cell debris was pelleted by centrifugation at $27,000 \times g$ for $20 \mathrm{~min}$. Supernatants containing soluble proteins were purified by recovering the $6 \times$ His$Z_{\text {ras122 }},-Z_{\text {ras220 }},-Z_{\text {ras521 }}$, and $-Z_{\text {raf322 }}$ fusion proteins after passage through nickel-chelated agarose columns (Thermo Fisher Scientific). The columns were equilibrated with $10 \mathrm{~mL}$ of B-PER Bacterial Protein Extraction Reagent before application of the supernatant. After washing the column with B-PER wash buffer, the bound proteins were released with elution buffer $(50 \mathrm{mM}$ Tris, $300 \mathrm{mM} \mathrm{NaCl}, 200 \mathrm{mM}$ imidazole, $10 \%$ [v/v] glycerol), according to a previous protocol (Shibasaki et al. 2013). The concentration of each protein was determined by the BCA assay (REF), and the molecular size was confirmed by SDS-PAGE.

\section{Affibody protein introduction into MH7A cells}

MH7A cells were seeded at $1.7 \times 10^{5}$ cells/well in a 24-well plate and cultured for $1 \mathrm{~d}$ before the introduction of the purified proteins. Each affibody protein $(5 \mu \mathrm{g})$ was mixed with Xfect Protein Buffer (Takara Bio, Shiga, Japan) to a total volume to $20 \mu \mathrm{L}$ and then mixed with Xfect Protein Transfection Reagent. As a negative control, PBS was used in the place of the affibody molecule. After substitution of culture medium with serum-free medium for the cells, a diluted protein mixture was added to cultured MH7A cells and incubated at $37^{\circ} \mathrm{C}$, according to a previous protocol (Kato et al. 2013).

\section{Statistical analysis}

Results are expressed as the mean \pm SD. The significance of the difference between the experimental results and control values was determined by Student's $t$-test. $P$ values less than 0.05 were considered significant.

\section{Results}

\section{Expression of affibody molecules in MH7A cells}

Each pcDNA3.1-based plasmid encoding $Z_{\text {ras122 }}, Z_{\text {ras220, }}$, or $Z_{\text {ras521 }}$ was designed to yield head-to-tail homodimers of the molecules. The plasmid encoding $Z_{\text {raf322 }}$ was designed to yield a monomeric molecule. Each plasmid was introduced into MH7A cells, and protein expression was confirmed by western blot analysis. The dimeric affibody molecules, $Z_{\text {ras122 }}, Z_{\text {ras220, }}$ and $Z_{\text {ras521 }}$, appeared to 
be approximately $12 \mathrm{kDa}$, and the monomeric affibody molecule, $Z_{\text {raf322 }}$, appeared to be approximately $6 \mathrm{kDa}$. The $Z_{\text {ras122 }}$ affibody protein was expressed in a greater quantity than the other affibody proteins at 48 and $72 \mathrm{~h}$ after transfection (Figure 1).

\section{Inhibition of IL-6 and PGE2 production by plasmid- expressed affibody proteins}

Each plasmid expressing the affibody molecules was introduced into MH7A cells to observe any inhibition of IL- 6 production. At $24 \mathrm{~h}$ after transfection, TNF- $\alpha$ was added to induce synthesis of IL-6 and PGE2 (Figure 1A). After an additional $24-48 \mathrm{~h}$ of culture, the supernatant was collected, and IL-6 production was evaluated by ELISA. $\mathrm{Z}_{\text {ras220 }}$ reduced IL-6 production by approximately $20 \%$ relative to the empty plasmid (pcDNA3.1) at 24 and $48 \mathrm{~h}$ after TNF- $\alpha$ stimulation; in contrast, expression of $\mathrm{Z}_{\text {raf322 }}$ reduced IL- 6 production by approximately $10 \%$ (Figure 2A). The inhibition of IL-6 production by each plasmid-expressed affibody was greater at $24 \mathrm{~h}$ than at $48 \mathrm{~h}$ after TNF- $\alpha$ stimulation (Figure 2A). Possible inhibition of PGE2 production in MH7A cells was also analyzed upon expression of the affibody molecules. Expression of $\mathrm{Z}_{\text {raf322 }}$ reduced PGE2 production by approximately $10 \%$ relative to the empty plasmid at $24 \mathrm{~h}$ after TNF- $\alpha$ stimulation, while expression of $Z_{\text {raf122. }} Z_{\text {ras220, and }} Z_{\text {ras521 }}$ did not significantly affect PGE2 expression at 24 h (Figure 2B). $\mathrm{Z}_{\text {ras122 }}$ and $\mathrm{Z}_{\text {raf322 }}$ reduced $\mathrm{PGE2}$ production by approximately $20 \%$ relative to the control plasmid at $48 \mathrm{~h}$ after TNF- $\alpha$ stimulation; in contrast to IL-6 production, the inhibition of PGE2 production by each plasmid-expressed affibody was greater at $48 \mathrm{~h}$ than at $24 \mathrm{~h}$ after TNF- $\alpha$ stimulation (Figure 2B).

\section{Phosphorylation of ERK}

ERK1/2 is situated downstream of Ras/Raf in the MAP kinase signal transduction cascade. To determine if affibody molecules affected signaling through this pathway, phosphorylation of ERK1/2 was evaluated in MH7A cells at 16 and $24 \mathrm{~h}$ after TNF- $\alpha$ stimulation. Western blot analysis of each cell lysate was performed, using an anti-p-ERK antibody with an anti-actin antibody serving as a control. The expression of $Z_{\text {ras220 }}$ inhibited phosphorylation of ERK1/2 at $16 \mathrm{~h}$ after TNF- $\alpha$ stimulation (Figure 3). This result indicated that $\mathrm{Z}_{\mathrm{ras} 220}$, but not the other affibody proteins, was able to block ERK1/2 phosphorylation through binding to Ras.

\section{Inhibition of IL- 6 and PGE2 production by affibody molecules as proteins in MH7A cells}

The affibody molecules were expressed in Escherichia coli and purified to $>95 \%$ purity. SDS-PAGE analysis of the fractions from the last chromatographic step

A

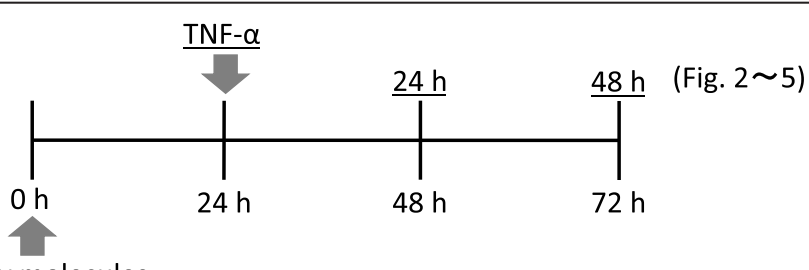

Affibody molecules

(as DNA or protein)

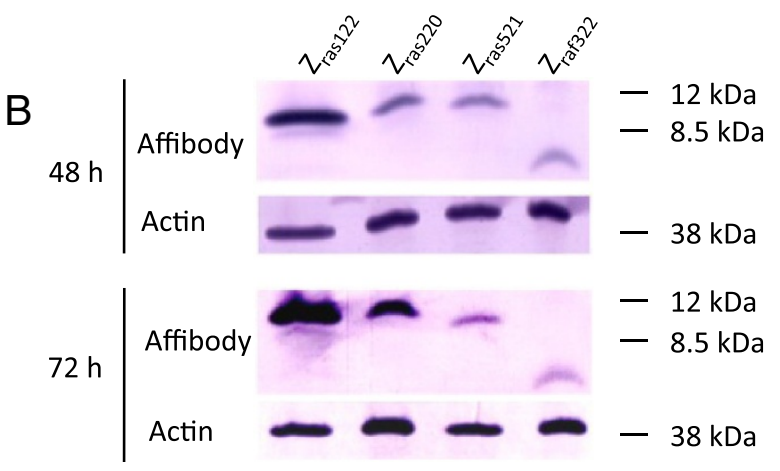

Figure 1 Experimental protocol (A) and western blot analysis for confirmation of cytosolic synthesis of affibody molecules (B). (A) Affibody molecules were introduced into MH7A cells encoded by DNA or as proteins. After 24-h culture, the cells were stimulated with TNF-a $(100 \mathrm{ng} / \mathrm{mL})$ and cultured for an additional 24-48 h. (B) Western blot analysis of each soluble fraction from MH7A cells harboring plasmid-encoded affibody protein molecules was analyzed at 48 and $72 \mathrm{~h}$ after the introduction of the plasmid into MH7A cells. Actin was analyzed as a control. 


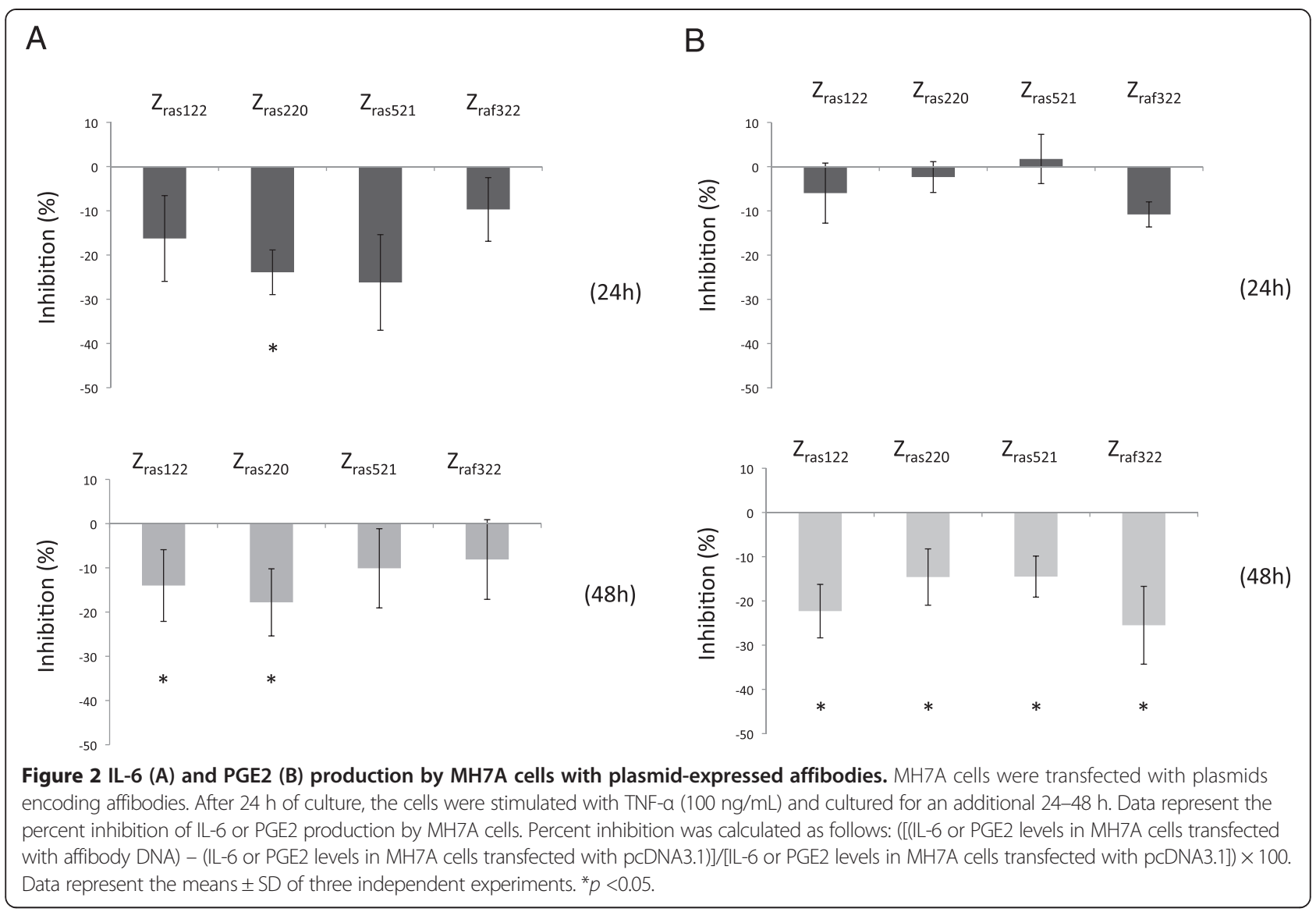

revealed essentially pure proteins of the expected molecular weight (data not shown). Individually, $Z_{\text {ras122, }}$ $Z_{\text {ras220 }}, Z_{\text {ras521 }}$, and $Z_{\text {raf322 }}$ proteins were introduced into MH7A cells by incubation with the cell-penetrating peptide reagent Xfect. Although the inhibition of IL-6

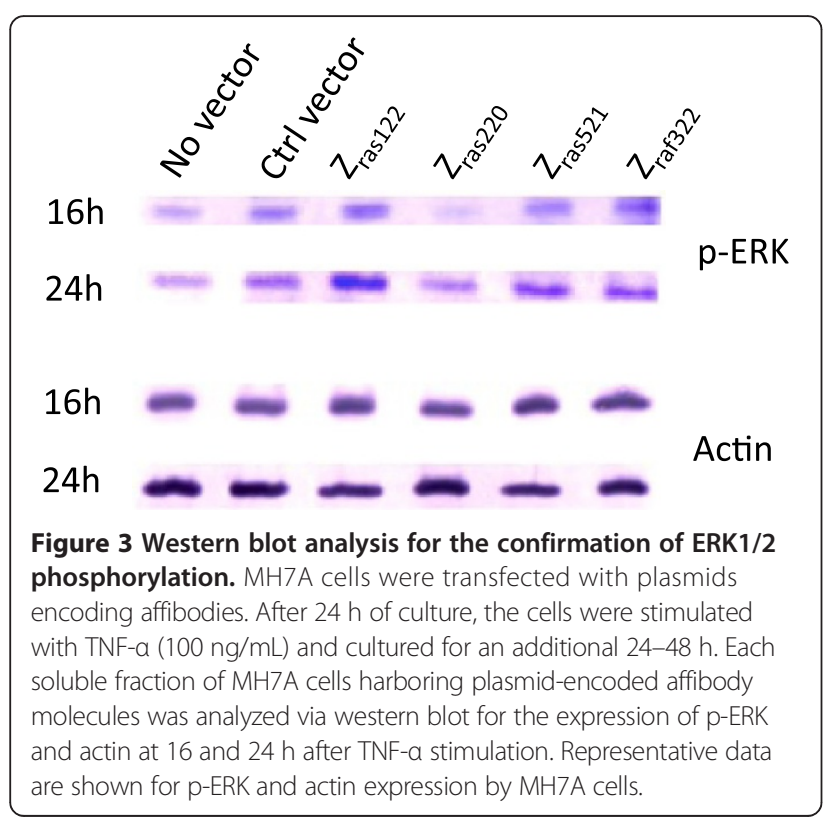

production by $\mathrm{Z}_{\text {ras122 }}$ was stronger than the inhibition by the other proteins at $24 \mathrm{~h}, \mathrm{Z}_{\text {ras220 }}$ protein strongly inhibited IL- 6 production by approximately $46 \%$ relative to the control penetrating peptide alone at $48 \mathrm{~h}$ after TNF- $\alpha$ stimulation (Figure $4 \mathrm{~A}$ ). The $\mathrm{Z}_{\text {ras220 }}$ protein also strongly inhibited PGE2 production by $32 \%$ relative to the control penetrating peptide alone at $48 \mathrm{~h}$ after TNF$\alpha$ stimulation (Figure 4B).

\section{Effect of affibody molecules on cell proliferation}

The proliferation of MH7A cells was also investigated upon expression of the affibody molecules by plasmid transfection. No change in proliferation could be observed at 24 or $48 \mathrm{~h}$ after TNF- $\alpha$ stimulation for any of the constructs, compared to the cells harboring the empty plasmid (Figure 5A). We next investigated a possible effect on MH7A cell proliferation after introduction of affibody proteins. MH7A cells transfected with a control peptide proliferated $151 \%$ from $0-24 \mathrm{~h}$, while those transfected with $\mathrm{Z}_{\mathrm{raf} 322}$ proteins proliferated almost $0 \%$ from $0-24 \mathrm{~h}$ (Figure 5B). Furthermore, during 0-48 h, control cells and $\mathrm{Z}_{\mathrm{raf} 322}$ proteins-transfected cells proliferated $327 \%$ and $291 \%$, respectively. These results indicate an inhibitory effect of $\mathrm{Z}_{\mathrm{raf} 322}$ protein introduction on proliferation. 


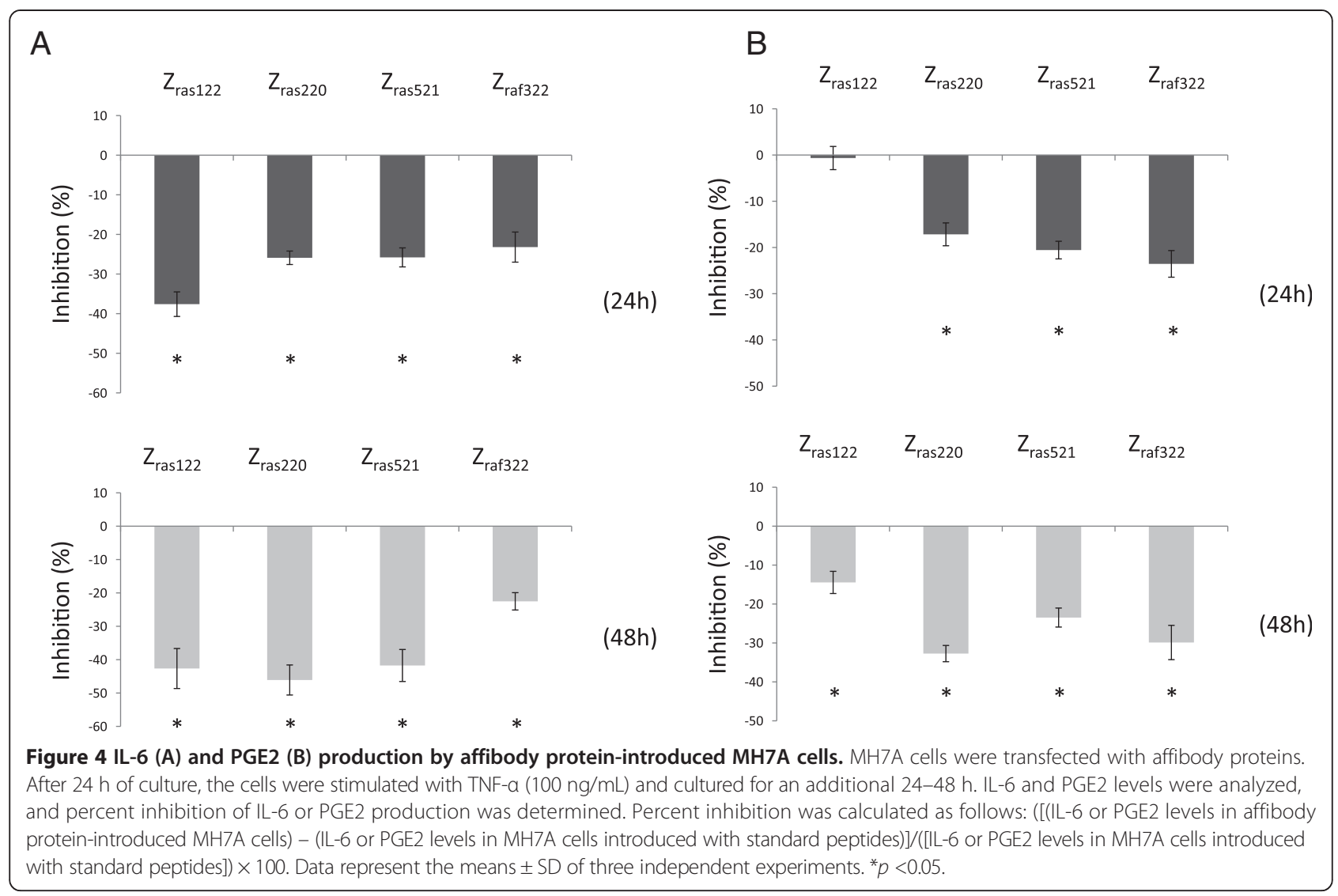

\section{Discussion}

In this study, we investigated whether affibody molecules targeting H-Ras or Raf-1 can inhibit cell proliferation and the production of inflammatory mediators in vitro. To date, it has been demonstrated that intracellularly expressed affibody molecules can bind to target molecules and inhibit their functions. For example, an affibody molecule that has an affinity for epidermal growth factor receptor (EGFR) retains EGFR in the secretory compartment. This constraint led to decreased phosphorylation of EGFR and a reduced proliferation rate (Vernet et al. 2009). An affibody molecule targeting HER3 inhibits proliferation of a cancer cell line (Göstring et al. 2012). However, we demonstrated for the first time that an affibody targeting intracellular signal transduction molecules could inhibit cell proliferation and the production of inflammatory mediators. We demonstrated that H-Ras- $\left(Z_{\text {ras122 }}, Z_{\text {ras220 }}, Z_{\text {ras521 }}\right)$ or Raf-1- $\left(Z_{\text {raf322 }}\right)$ targeting affibody molecules inhibited the production of IL-6 and PGE2 in a synovial cell line. These affibody molecules were introduced into the cells via DNAencoding plasmids or as purified proteins. In both cases, inhibition of IL-6 and PGE2 production was observed for almost all affibody molecules.

Several previous reports indicated suppression of synovial cell function by Ras inhibition. For instance, gene transfer of a dominant negative mutant of the Ras gene (Yamamoto et al. 2003) or gene silencing using a locked nucleic acid against Ras (de Launay et al. 2010) in synovial cells inhibited the production of inflammatory mediators, such as IL-6. Consistent with these reports, we observed that affibody molecules binding to $\mathrm{H}$-Ras or Raf- 1 could inhibit the production of IL-6. PGE2 production by RA synovial cells is regulated by Ras (Na et al. 2004). Therefore, we analyzed PGE2 levels and demonstrated that these affibody molecules also inhibited PGE2 production. Matrix metalloproteinase (MMP)-3 is a protease that is produced by synovial cells upon TNF- $\alpha$ stimulation, and its production is regulated by Ras (Abreu et al. 2009). We analyzed MMP-3 levels and demonstrated that these affibody molecules also inhibited MMP-3 production (data not shown). These results indicate that affibody molecules binding to H-Ras or Raf- 1 can inhibit inflammatory mediators or proteases, such as IL-6, PGE2, and MMP-3, which are crucial to RA pathogenesis.

Regarding the expression of affibody molecules in MH7A cells, we observed stronger expression of $Z_{\text {ras122 }}$ than other affibody proteins. In addition, $Z_{\text {ras122 }}$ protein levels increased, while $Z_{\text {raf322 }}$ and $Z_{\text {ras521 }}$ protein levels decreased between 24 and $48 \mathrm{~h}$ (Figure 1). These results might be related to the stability of the $\mathrm{Z}_{\text {ras122 }}$ affibody protein afforded by the plasmid construct. Supporting this notion, we 

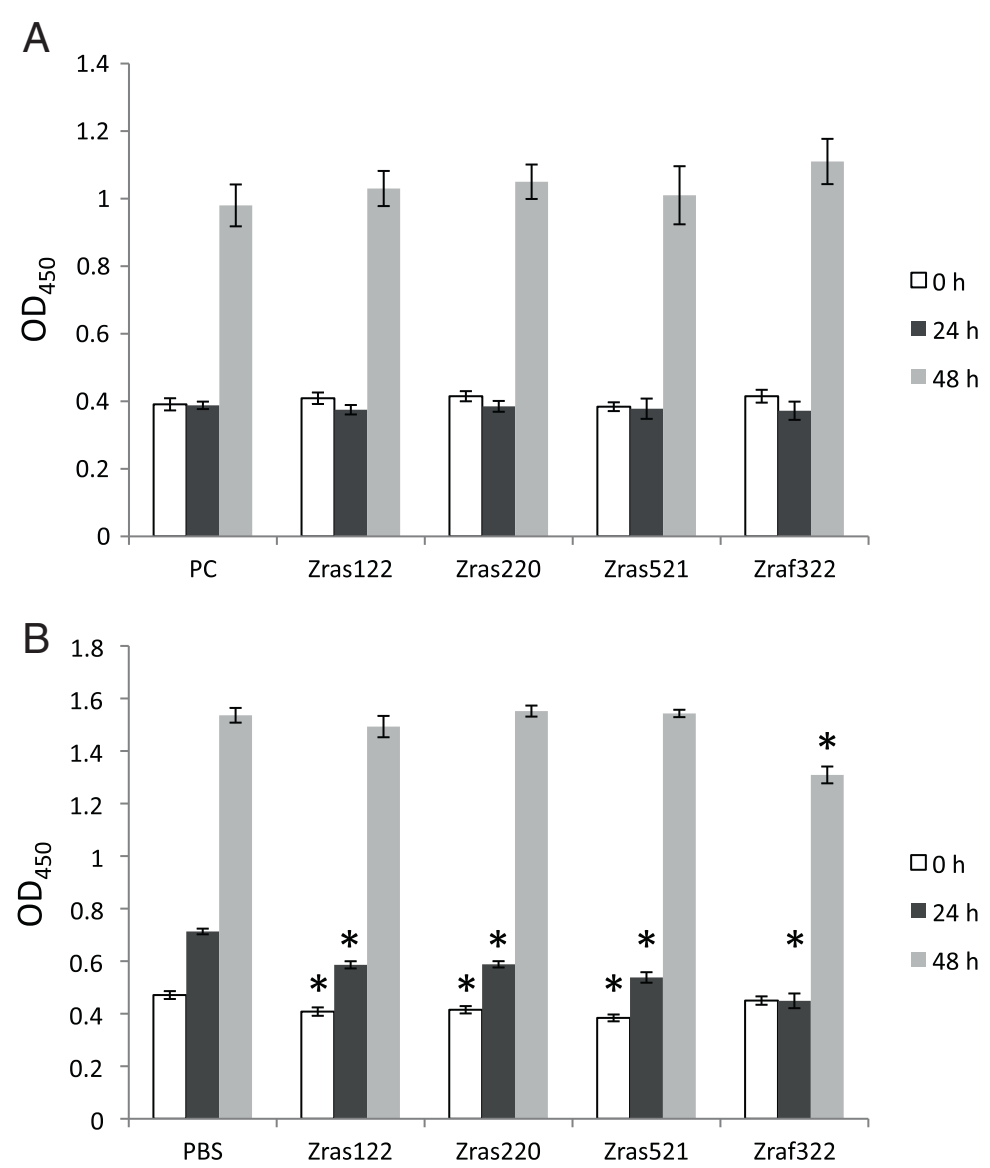

Figure 5 Cell proliferation assay for MH7A cells transfected with plasmid-expressed affibody molecules (A) and MH7A cells introduced affibody molecules as protein (B). After $24 \mathrm{~h}$ of culture, the cells were stimulated with TNF-a $(100 \mathrm{ng} / \mathrm{mL})$ and cultured for an additional $24-48 \mathrm{~h}$. Cell proliferation was analyzed with a CCK assay. Data represent the means \pm SD of three independent experiments. ${ }^{*} p<0.05$.

observed that $\mathrm{Z}_{\text {ras220 }}$ and $\mathrm{Z}_{\text {ras521 }}$ inhibited IL-6 production by $23.9 \%$ and $26.2 \%$ relative to the control vector treatment at $24 \mathrm{~h}$, while these inhibitory effects were decreased to $17.8 \%$ and $10.1 \%$ at $48 \mathrm{~h}$ after TNF- $\alpha$ stimulation, respectively. In contrast, inhibition by $\mathrm{Z}_{\text {ras122 }}$ was maintained up to $48 \mathrm{~h}$ after TNF- $\alpha$ stimulation (Figure 2A), suggesting increased stability of the affibody. With regard to PGE2 production, inhibition by all affibodies at $48 \mathrm{~h}$ increased compared with that at $24 \mathrm{~h}$ after TNF- $\alpha$ stimulation. Of interest, the timing of maximal inhibition was different for IL-6 and PGE2, but the underlying mechanism is still unknown. The difference could be attributed to the difference in the signal transduction cascade of these inflammatory molecules.

To determine whether affibody molecules inhibit signal transduction via ERK, we examined the phosphorylation of ERK1/2, a downstream molecule of Ras/Raf signaling. $Z_{\text {ras220 }}$ inhibited ERK1/2 phosphorylation in the early stage (16 h) after stimulation by TNF- $\alpha$ (Figure 3 ), although we did not observe distinct inhibition by other affibodies. This transient inhibition of ERK1/2 phosphorylation might be caused relatively by $\mathrm{Z}_{\text {ras220 }}$ via interruption of the interaction between Raf-1 and MEK1/2 (Chen et al. 2001). However, this inhibition on ERK1/2 phosphorylation could not be kept after 16-24 h, so that differences of phosphorylation among all affibody molecules here should be investigate more precisely in further study.

We utilized two different methods to deliver affibody molecules into synovial cells: 1) transfection of plasmids encoding the affibody molecules and 2) introduction of affibody proteins using a cell-penetrating peptide reagent. Protein-introduced affibody molecules exhibited stronger inhibition of IL- 6 and PGE2 production than plasmidexpressed affibody molecules (Figures 2 and 4). Moreover, the inhibition resulting from the introduced proteins was less variable than that resulting from plasmid transfection. When cell proliferation was examined using plasmid-encoded affibody molecules, distinctive differences were not observed (Figure 5A). On the contrary, introduction of $Z_{\text {raf322 }}$ proteins partially inhibited cell proliferation (Figure 5B), suggesting that a plasmidbased expression system did not generate a sufficient 
concentration of affibody in MH7A cells to inhibit signal transduction. In the experiments using plasmids, cell proliferation was not observed at 24 (Figure 5A), while in the experiments using proteins, cell proliferation was observed at the same period (Figure 5B). This might be based on higher cytotoxicity of liposome compared with peptides used as a carrier (Suhorutsenko et al. 2011). These results indicate that protein-introduced affibody molecules more effectively inhibited cytokine production and cell proliferation in synovial cells than plasmid-expressed affibody molecules. Although the effect on synovial cell proliferation was not strong, our results demonstrate that it is possible to inhibit synovial cell proliferation by selecting useful affibody clones and by improving transduction efficiency of affibody protein molecules.

Inhibition of IL- 6 and PGE2 production caused by the protein-introduced affibodies varied. For example, at $48 \mathrm{~h}$ after TNF- $\alpha$ stimulation, inhibition of IL- 6 production was greater than $40 \%$ for three affibodies $\left(Z_{\text {ras122 }}, Z_{\text {ras220, }}\right.$, and $\left.Z_{\text {ras521 }}\right)$, whereas that of PGE2 was approximately $30 \%$ for two affibodies $\left(Z_{\text {ras220 }}\right.$ and $\mathrm{Z}_{\text {raf322 }}$ ). These results could be attributed to the fact that the PGE2 receptor, which couples with G proteins, is integrated into a positive feedback loop for PGE2 production (Nishimura et al. 2013); thus, the effect of an affibody molecule on PGE2 production might be weaker than on IL-6. The differential effectiveness of each affibody molecule on synovial cell function might also be explained by differences in the amino acid sequences of the affibodies themselves. Each clone was selected using a phage display library of $\mathrm{Z}$ variants, and the amino acid sequences encoded by each clone are different.

In conclusion, we demonstrated that affibody molecules could inhibit cell proliferation and the production of inflammatory mediators by blocking the Ras/Raf signal transduction cascade. Although inhibition of cell function could be enhanced, and delivery methods should be examined further, we propose that these molecules are candidates to be investigated as a molecular-targeting therapy for RA. Studies are in progress to select useful affibody clones, to improve delivery methods of affibody protein molecules, and to verify the efficiency of affibodies in an RA model.

\section{Additional file}

Additional file 1: DNA sequence of affibody molecules in this study.

\section{Competing interests}

The authors declare that they have no competing interest.

\section{Authors' contributions}

SS, TG and PN carried out the genetic construction of affibody molecules. MK carried out Western blot analysis and ELISA. SS and MK carried out cell proliferation assays and productions of affibody molecules using E. coli. HS and TI participated in the design, coordination of the study. SS, TG, PN and $\mathrm{TI}$ contributed in the drafting of the manuscript. All authors read and approved the final manuscript.

\section{Acknowledgements}

This work was partially supported by the Ministry of Education, Culture, Sports, Science and Technology, Japan, with a Grant-in-Aid for Young Scientists (B).

\section{Author details}

${ }^{1}$ General Education Center, Hyogo University of Health Sciences, 1-3-6 Minatojima, Chuo-ku, Kobe 650-8530, Japan. ${ }^{2}$ Graduate School of Pharmacy, Hyogo University of Health Sciences, 1-3-6 Minatojima, Chuo-ku, Kobe 650-8530, Japan. ${ }^{3}$ Division of Rheumatology, Department of Internal Medicine, Hyogo College of Medicine, 1-1Mukogawa-cho, Nishinomiya 663-8501, Japan. ${ }^{4}$ Department of Molecular Biotechnology, School of Biotechnology, Royal Institute of Technology (KTH), AlbaNova University Center, SE-106 91 Stockholm, Sweden. ${ }^{5}$ Division of Pharmacotherapy, Department of Pharmacy, School of Pharmacy, Hyogo University of Health Sciences, 1-3-6 Minatojima, Chuo-ku, Kobe 650-8530, Japan.

Received: 26 September 2014 Accepted: 31 October 2014

Published online: 11 November 2014

\section{References}

Abreu JR, de Launay D, Sanders ME, Grabiec AM, van de Sande MG, Tak PP, Reedquist KA (2009) The Ras guanine nucleotide exchange factor RasGRF1 promotes matrix metalloproteinase-3 production in rheumatoid arthritis synovial tissue. Arthritis Res Ther 11:R121

Baumann MJ, Stadler BM, Vogel M (2007) Potential applications of designed ankyrin repeat proteins in diagnostics and therapeutics. Exp Opin Med Diagn 1:409-421

Chen J, Fujii K, Zhang L, Roberts T, Fu H (2001) Raf-1 promotes cell survival by antagonizing apoptosis signal-regulating kinase 1 through a MEK-ERK independent mechanism. Proc Natl Acad Sci U S A 98:7783-7788

de Launay D, Vreijling J, Hartkamp LM, Karpus ON, Abreu JR, van Maanen MA, Sanders ME, Grabiec AM, Hamann J, Ørum H, Vervoordeldonk MJ, Fluiter K, Tak PP, Reedquist KA (2010) Silencing the expression of Ras family GTPase homologues decreases inflammation and joint destruction in experimental arthritis. Am J Pathol 177:3010-3024

Friedman M, Ståhl S (2009) Engineered affinity proteins for tumour-targeting applications. Biotechnol Appl Biochem 53:1-29

Furneri G, Mantovani LG, Belisari A, Mosca M, Cristiani M, Bellelli S, Cortesi PA, Turchetti G (2012) Systematic literature review on economic implications and pharmacoeconomic issues of rheumatoid arthritis. Clin Exp Rheumatol 30:572-S84

Gómez-Reino J (2012) Biologic monotherapy as initial treatment in patients with early rheumatoid arthritis. Rheumatology 51(Suppl 5):v31-v37

Göstring L, Malm M, Höidén-Guthenberg I, Frejd FY, Ståhl S, Löfblom J, Gedda L (2012) Cellular effects of HER3-specific affibody molecules. PLoS One 7:e40023

Grimm S, Lundberg E, Yu F, Shibasaki S, Vernet E, Skogs M, Nygren PÅ, Gräslund $T$ (2010) Selection and characterisation of affibody molecules inhibiting the interaction between Ras and Raf in vitro. N Biotechnol 27:766-773

Gunneriusson E, Samuelson P, Uhlen M, Nygren PA, Stähl S (1996) Surface display of a functional single-chain Fv antibody on staphylococci. J Bacteriol 178:1341-1346

Kato T, Tanaka M, Oba M (2013) Protein transfection study using multicellular tumor spheroids of human hepatoma Huh-7 cells. PLoS One 8:e82876

Kitano M, Hla T, Sekiguchi M, Kawahito Y, Yoshimura R, Miyazawa K, Iwasaki T, Sano H, Saba JD, Tam YY (2006) Sphingosine 1-phosphate/sphingosine 1-phosphate receptor 1 signaling in rheumatoid synovium: regulation of synovial proliferation and inflammatory gene expression. Arthritis Rheum 54:742-753

Koide A, Wojcik J, Gilbreth RN, Hoey RJ, Koide S (2012) Teaching an old scaffold new tricks: monobodies constructed using alternative surfaces of the FN3 scaffold. J Mol Biol 415:393-405 
Lindberg H, Hofström C, Altai M, Honorvar H, Wållberg H, Orlova A, Ståhl S, Gräslund T, Tolmachev V (2012) Evaluation of a HER2-targeting affibody molecule combining an N-terminal HEHEHE-tag with a GGGC chelator for 99mTc-labelling at the $C$ terminus. Tumour Biol 33:641-651

Lundberg E, Brismar H, Gräslund T (2009) Selection and characterization of Affibody ligands to the transcription factor c-Jun. Biotechnol Appl Biochem 52:17-27

Malm M, Kronqvist N, Lindberg $H$, Gudmundsdotter L, Bass T, Frejd FY, Höidén-Guthenberg I, Varasteh Z, Orlova A, Tolmachev V, Ståhl S, Löfblom J (2013) Inhibiting HER3-mediated tumor cell growth with affibody molecules engineered to low picomolar affinity by position-directed error-prone PCR-like diversification. PLoS One 8:e62791

Mélet J, Mulleman D, Goupille P, Ribourtout B, Watier H, Thibault G (2013) Rituximab-induced $T$ cell depletion in patients with rheumatoid arthritis: association with clinical response. Arthritis Rheum 65:2783-2790

Miyazawa K, Mori A, Okudaira H (1998) Establishment and characterization of a novel human rheumatoid fibroblast-like synoviocyte line, MH7A, immortalized with SV40 T antigen. J Biochem 124:1153-1162

Na HJ, Lee SJ, Kang YC, Cho YL, Nam WD, Kim PK, Ha KS, Chung HT, Lee H, Kwon YG, Koh JS, Kim YM (2004) Inhibition of farnesyltransferase prevents collagen-induced arthritis by down-regulation of inflammatory gene expression through suppression of p21(ras)-dependent NF-kappaB activation. J Immunol 173:1276-1283

Nilsson FY, Tolmachev V (2007) Affibody molecules: new protein domains for molecular imaging and targeted tumor therapy. Curr Opin Drug Discov Devel 10:167-175

Nishimura T, Zhao X, Gan H, Koyasu S, Remold HG (2013) The prostaglandin E2 receptor EP4 is integral to a positive feedback loop for prostaglandin E2 production in human macrophages infected with Mycobacterium tuberculosis. FASEB J 27:3827-3836

Nygren PA (2008) Alternative binding proteins: affibody binding proteins developed from a small three-helix bundle scaffold. FEBS J 275:2668-2676

Ohuchida T, Okamoto K, Akahane K, Higure A, Todoroki H, Abe Y, Kikuchi M, Ikematsu S, Muramatsu T, Itoh H (2004) Midkine protects hepatocellular carcinoma cells against TRAlL-mediated apoptosis through down-regulation of caspase-3 activity. Cancer 100:2430-2436

Olsen NJ, Stein CM (2004) New drugs for rheumatoid arthritis. N Engl J Med $350: 2167-2179$

Saag KG, Teng GG, Patkar NM, Anuntiyo J, Finney C, Curtis JR, Paulus HE, Mudano A, Pisu M, Elkins-Melton M, Outman R, Allison JJ, Suarez Almazor M, Bridges SL, Jr, Chatham WW, Hochberg M, MacLean C, Mikuls T, Moreland LW, O'Dell J, Turkiewicz AM, Furst DE, American College of Rheumatology (2008) American College of Rheumatology 2008 recommendations for the use of nonbiologic and biologic disease-modifying antirheumatic drugs in rheumatoid arthritis. Arthritis Rheum 59:762-784

Schlegel PM, Steiert I, Kötter I, Müller CA (2013) B cells contribute to heterogeneity of IL-17 producing cells in rheumatoid arthritis and healthy controls. PLoS One 8:e82580

Shibasaki S, Fujita A, Usui C, Watanabe S, Kitano S, Sano H, Iwasaki T (2012) Effect of transient expression of fluorescent protein probes in synovial and myoblast cell lines. Springer Plus 1:36

Shibasaki S, Aoki W, Nomura T, Miyoshi A, Tafuku S, Sewaki T, Ueda M (2013) An oral vaccine against candidiasis generated by a yeast molecular display system. Pathog Dis 69:262-268

Smolen JS, Aletaha D (2011) Interleukin-6 receptor inhibition with tocilizumab and attainment of disease remission in rheumatoid arthritis: the role of acute-phase reactants. Arthritis Rheum 63:43-52

Smolen JS, Steiner G (2003) Therapeutic strategies for rheumatoid arthritis. Nat Rev Drug Discov 2:473-488

Suhorutsenko J, Oskolkov N, Arukuusk P, Kurrikoff K, Eriste E, Copolovici DM, Langel U (2011) PepFects, show no evidence of toxicity and immunogenicity in vitro and in vivo. Bioconjug Chem 22:2255-2262

Tsunemi S, Iwasaki T, Kitano S, Imado T, Miyazawa K, Sano H (2010) Effects of the novel immunosuppressant FTY720 in a murine rheumatoid arthritis model. Clin Immunol 136:197-204

Upchurch KS, Kay J (2012) Evolution of treatment for rheumatoid arthritis. Rheumatology 51(Suppl 6):vi28-vi36
Vernet E, Lundberg E, Friedman M, Rigamonti N, Klausing S, Nygren PA, Gräslund T (2009) Affibody-mediated retention of the epidermal growth factor receptor in the secretory compartments leads to inhibition of phosphorylation in the kinase domain. N Biotechnol 25:417-423

Yamamoto A, Fukuda A, Seto H, Miyazaki T, Kadono Y, Sawada Y, Nakamura I, Katagiri H, Asano T, Tanaka Y, Oda H, Nakamura K, Tanaka S (2003) Suppression of arthritic bone destruction by adenovirus-mediated dominant-negative Ras gene transfer to synoviocytes and osteoclasts. Arthritis Rheum 48:2682-2692

doi:10.1186/s13568-014-0082-3

Cite this article as: Shibasaki et al:: Inhibitory effects of H-Ras/Raf-1-binding

affibody molecules on synovial cell function. AMB Express 2014 4:82.

\section{Submit your manuscript to a SpringerOpen ${ }^{\circ}$ journal and benefit from:}

- Convenient online submission

- Rigorous peer review

- Immediate publication on acceptance

- Open access: articles freely available online

- High visibility within the field

- Retaining the copyright to your article

Submit your next manuscript at $>$ springeropen.com 